\title{
THE CORRELATIONS AMONG LEARNING MOTIVATION, WRITING ANXIETY AND NARRATIVE WRITING ACHIEVEMENT OF THE ELEVENTH GRADERS OF SMA ETHIKA PALEMBANG
}

\author{
Despita \\ STIA Satya Negara Palembang \\ Email: despita.kurniawan@gmail.com \\ Icha Pratiwi \\ STIA Satya Negara Palembang \\ Email: icha.yamin85@gmail.com
}

\begin{abstract}
Writing English text is basic competence that students must be common to write because writing plays an important role to enable the students to describe their ideas in logical and in a communicative way. The objectives of this research were to find out whether or not there was a significant correlation between learning motivation together with writing anxiety and writing achievement. The method used was descriptive method and the design was in the form of correlational research. By using total sample, 97 students of SMA ETHIKA Palembang were chosen as the sample of this research. Two questioners and writing test were administered to collect the data. The research results show that (a) there was a positive significant correlation between learning motivation and writing achievement $(\mathrm{r}=0.845)$, (b) there was no significant correlation between writing anxiety and writing achievement $(\mathrm{r}=-0.053)$, (c) the multiple correlation analysis of all independent variables showed a positive and significant correlation $(\mathrm{r}=0.845)$. Regression analysis showed that learning motivation influenced or contributed partially $84.5 \%$ to writing achievement and writing anxiety partially contributed $5,3 \%$, the combination of learning motivation together with writing anxiety contributed $71.5 \%$ to writing achievement.
\end{abstract}

Key Words: Learning Motivation, Writing Anxiety and Writing Achievement

\section{INTRODUCTION}

As foreign language students there are four kinds of language skills to be mastered in learning English, namely: listening, speaking, reading, and writing. Accordingly, listening and reading role as receptive skills while speaking and writing as the productive skills. In teaching learning process writing is basic competence that students must be common to write because writing plays an 
important role to enable the students to describe their ideas in logical and in a communicative way. In the field of language teaching and learning, even though students are mostly commanded to write text, it is still hard to find students who to some extent can cope with writing difficulties. For this reason, writing has long been claimed as a very difficult skill to acquire and is dreaded by L2/FL students (Gupta in Anggraini, 2012:1) this case might be mainly caused by the fact that written text production is complex by nature and requires plenty of procedures (Hedge, 2000:7) in other words, the success of writing is associated with a high degree of organization, accuracy, the use of complex grammatical, self expression, flow of ideas and confidence. That is why it is assumed that students do not feel any enjoyment during writing process because of these problems.

The fact of writing is seen as psychological activity of the language user to put information in the written text (Siahaan, 2008:215) and the demands of language features (Hedge, 1992:7) all make foreign language students anxious to be involved in writing. It is claimed that there will be personality factor that might unlikely affect students' writing achievement, in the eye of foreign language learning, psychologically, one kind of affective factors in language learning comes across with the term "anxiety". Anxiety is defined as "students' inability in communication, fear of negative social evaluation, and test anxiety" (Brown, 2007:162). That is to say, under the discussion of language, it is now known as language anxiety, in the focus of writing anxiety.

Concerning the findings that showed students' learning motivation as the influential factor for students' anxiety, it is also important to see how the teachers' motivation plays a role in stimulating the students to have positive motivation because learning motivation is one of several important factors that may influence students' achievement. It provides the students with a strong reason for doing something. It is powerful affective variable in second language acquisition, and it has great influence on foreign language learning. Learning motivation in language learning also affects to students' achievement in English. It is assumed that the students with high motivation in learning English will be more successful than those who have low motivation. The stronger the motivation the students get the more quickly they will learn a language. The motivation which students bring to 
the class is the biggest single factor affecting their success, it's show that motivation in the classroom affects both spirit and enthusiasm behavior of the students who are motivated to learn.

Similar as what has been preceding described, the problems of writing were also faced by the eleventh grade of SMA ETHIKA PALEMBANG through personal observation by interviewing the teacher of English and the eleventh grade students of SMA ETHIKA Palembang. They got low score in writing skill, in the last meeting of writing assessment most of students could not get score higher than Minimum Completeness Criterion.

In the observation the researcher found that there were two factors which make the students' writing score low, they are learning motivation and writing anxiety. The first in learning motivation, for examples: 1) the students are not interested in learning English subject 2) they feel lazy to read English books, 3) it is difficult for them to read the English books, 4) there are not many English books at school. The second that makes students' writing score is low is writing anxiety, for examples: 1) it is difficult for the students to write text, 2) most of them were lack of vocabulary and afraid of their grammar, 3) the students are afraid being mistakes in English writing, 4) and some condition, such as writing evaluation and writing in unexpected instruction. All these empirical data imply that teachers of English are required to boost up such kind of great efforts toward literacy skill.

Considering that the issue of correlation among learning motivation, writing anxiety and writing achievement is worth discussing, the researcher is interested in conducting a research entitled: "The Correlations among Learning Motivation, Writing Anxiety and Writing Achievement of The Eleventh Graders of SMA ETHIKA Palembang", this strategy may help the teacher and the students of SMA ETHIKA Palembang needs in teaching learning process of studying writing achievement.

The research focus on The Correlation among learning motivation, writing anxiety and Writing Achievements of the Eleventh Graders of SMA ETHIKA Palembang. The main problem of this study was " Are there any correlation 
among learning motivation, writing anxiety and narrative writing achievement of the eleventh graders of SMA ETHIKA Palembang"

The objectives of this study was to find out whether or not there are correlation among learning motivation, writing anxiety and narrative writing achievement of the eleventh graders of SMA ETHIKA Palembang

Brown and Gardner categorized motivation into two types; they are integrated motivation and instrumental motivation.

Integrated Motivation

Motivation is defined as the learner's orientation with regard to the goal of learning a second language. It is thought that students who are most successful when learning a target language are those who like the people that speak the language, admire the culture and have a desire to become familiar with or even integrate into the society in which the language is used. This form of motivation is known as integrate motivation. Integrate motivation is characterized by the student's positive attitudes towards the target language group and the desire to integrate into the target language community. When someone become a resident in a few community that uses the target language in its social interaction, integrated motivation is a key component in assisting the student to develop some level of proficiency the language.

\section{Instrumental Motivation}

In contras to integrated motivation is the form of motivation referred to as instrument motivation. It is functional reason for learning the target language, such as job promotion, or a language requirement. This is generally characterized by the desire to obtain something practical or concrete from the study of a second language. With instrumental motivation the purpose of language acquisition is more utilitarian, instrumental motivation is often characteristic of second language acquisition, where little or no social integration of the student into a community using the target language takes place, or in some instances is even desired. 
Narayan (2008:486) characterizes a motivated student as 1)positive task orientation: The student is willing to tackle tasks and challenges, and has confidence in his or her success, 2) Ego-involvement : The student finds it important to succeed in learning in order to maintain and promote his or her own self-image, 3) need for achievement: The student has a need to achieve, to overcome difficulties and succeed in what he or she sets out to do, 4) high aspiration: The student is ambitious, goes for demanding challenges, high proficiency, top grades, 5) Goal orientation: The student is well aware of the goals of learning, or of specific learning activities, and directs his or her efforts towards achieving them, 6) Perseverance: The student consistently invests a high level of effort in learning, and is not discouraged by set backs or apparent lack of progress, 7) Tolerance of ambiguity: the student is not disturbed of frustrated by situation involving a temporary lack of understanding or confusion; he or she can live with these patiently, in the confidence that understanding will come later. So it can be conclude that students' motivation has been widely accepted as a key factor which influences the rate and success of second/foreign language learning.

Lefrancois (1997:348) says that anxiety is the effect of when arousal is too high. Lefrancois defines anxiety as "a feeling characterized by varying degrees of fear and worry, also it refers to mental disorder". Graham (1997:116) also argued that anxiety may have a positive as well as a negative effect in terms of motivating students in learning. It can e concluded that positive effect of anxiety may contribute to the students' achievement, while negative one distracts.

if language anxiety is related to writing achievement, it is named writing anxiety (Rose, 1987:7). The sources of writing anxiety are derived from the term of evaluation apprehension, stress apprehension, and product apprehension. As a result, it might effect to students' writing achievement, either positively or negatively. Study showed that students showed their anxiety toward writing through nervousness and worry (Cheng, 2004:330), as a result, the effect of feeling anxious significantly makes some differences toward students' writing achievement. For some students, feeling anxious toward writing seriously decreases achievement because of lack of knowledge about written features, like vocabulary, grammar, punctuation, spelling and capitalization. 
Writing is a productive skill by which the students will create the written text; writing is also the way how authors communicate their ideas to the readers. According to Tarigan (2008:3) "writing is a skill used to communicate indirectly, not face to face with others." Writing is an important part in our global society. Through writing people can learn a lot of things. Writing can be a means of communication.

"Narrative text refers to telling of a story or an account of a sequence of events." Sedarwati (2007:40). One of the four traditional forms of composition (along with description, exposition, and persuasion) Narration differs from exposition, which can also relate a sequence of events, in that narration need not be factual and may be written from the perspective of a character in the text, Kinds of narrative text such as: fable, romance, horror, fairy story, and mystery. According to Budiyani (2013: 56) there are five points in design of narrative text: Plot, Setting, Characterization, Structure, Theme.

\section{METHODOLOGY}

\section{Method of research}

This research is quantitative research with correlational research design, because there are correlation between X1 and X2, and Y. Sugiyono (2012:7) states "quantitative research is research that the research data in the form of numeral and analysis used statistics."

This research has three variables that will research. In this research there are two independent variables, they are learning motivation as X1 and writing anxiety as $\mathrm{X} 2$, the dependent variable is writing achievement as Y. According to Arikunto (2010:159) "a variable is defined as something that varies from one case to another." The dependent variable is variable which one observe and measure to determine the effect of the independent variable. Independent variable (the major variable) is the variable which is selected, manipulated and measured by the researcher.

According to Emzir (2008:45) "predictive study concerns if any significant correlation between two independent variables on dependent variable." It means that, independent variable and dependent variables are having close correlation 
and influence with each other. Variable which became base of making prediction called as predictor and variable which is predicted called as criteria.

\section{Population and Sample}

According to Arikunto (2010:173) "population is all the subjects of research." It means that population is all the subjects which have the same characteristic. Sugiyono (2012:80) states that "population is generalization region which consist of subject or object which had special quality and characteristic to learn and take conclusion Therefore, the population in this research is all the eleventh grade of SMA ETHIKA Palembang that consists of three classes.

Sample is a limited number of elements from a proportion to represent population. Sugiyono (2012:81) states that "sample is part of number and characteristic that are owned by population." Creswell (2011:142) defines that a sample is a subgroup of the target population that the researcher plans to study for generalizing about the target population. To facilitate the representative sample from the population, Fraenkel, Wallen, and Hyun (2011:338) suggest that the minimum acceptable sample size for a correlational study is considered by most researchers to be no less than 30 .

Based on the preceding theories it is believed that the larger number of the sample will create the more representative sample for the research. Therefore, in this research the total number of population (the eleventh grade students of SMA ETHIKA Palembang).

\section{Technique for collecting data}

According to Arikunto (2010:266) "data collecting tool that is collected in quantitative research can be conducted by giving the test to measure the subject that will be observed." In this research, the data were collected by giving the tests to the students. Moreover, in applying the test the researcher had a questionnaire for learning motivation and writing enxiety, then test for writing narrative text. The procedure of testing is that the researcher gave a try out test to students which consist of 50 items for learning motivation and 30 items for writing enxiety. This research was done until two meetings. The first meeting was about learning motivation, and second meeting was about writing anxiety. After that researcher 
was helped by teacher of English in the school to collect the data after the students did the test. It was conducted to find out the students' achievement in two of variables. For writing achievement was not done try out because the instrument is essay test so it is construct validity that used experts judgment.

\section{RESEARCH RESULT}

There are three hypotheses had to be tested in this research. They are (1) H0: there is no significant correlation between students' learning motivation and their writing achievement and Ha: there is significant correlation between students' learning motivation and their writing achievement achievement, (2) H0: there is no significant correlation between students' writing anxiety and their writing achievement and Ha: there is significant correlation between students' writing anxiety and their writing achievement, (3)H0: there is no significant correlation between students' learning motivation, writing anxiety, and their writing achievement and Ha: there is significant correlation between students' learning motivation, writing anxiety, and their writing achievement.

To analyze the correlation among three variables above, multiple correlation(Ryx1x2) was used, and the analysis of their regression was used multiple linier regression formula in SPSS Program for Windows.

The result from the first hyphotesis proved there was significant correlation between students' learning motivation (X1) and writing achievement $(\mathrm{Y})$. The result of Ryx $1=0.845$ is included in high interpretation, and $\mathrm{X} 1$ gave influence $71.4 \%$ toward Y. From linear regression analysis, it showed that regression between $\mathrm{X} 1$ and $\mathrm{Y}$ is Fcount $=237.502>$ Ftable(96)=1.77, It means that linear and significant. Learning motivation is one of the factors that can influence of writing achievement, if they have high motivation in learning, they will get good result in writing. Learning motivation can influence the result of writing achievement.

The second result of hyphotesis proved there was significant correlation between students' writing anxiety (X2) writing achievement (Y) with Ryx2 is 0.053 which included in high interpretation. In the same case, X2 gave the influence $-0.3 \%$ toward Y. From linear regression analysis, it showed that 
regression between $\mathrm{X} 2$ and $\mathrm{Y}$ is Fcount $=0.267>\operatorname{Ftable}(96)=1.77$. It means that the regression is not linear and significant.

The third hyphotesis on the correlation and regression between students' Learning motivation (X1), writing anxiety (X2), and writing achievement with Ryx $1 \times 2=0.845$. Based on the result, the correlation is very high interpretation, . In the same case, X1 X2 gave the influence $71.5 \%$ toward Y In this research, there is significant correlation. From multiple regression analysis it showed that regression among $\mathrm{X} 1, \mathrm{X} 2$, and $\mathrm{Y}$ is Fcount $=117,660>$ Ftable $(96)=1.77$. It means that the regressions of three variables are linear and significant.

\section{CONCLUSION}

Based on the result of the data analysis, the researcher can conclude four matter as follows:

The first is the correlation between students' learning motivation (X1) and writing achievement $(\mathrm{Y})$ is Ryx $1=0.845$, consequently, there is correlation between $\mathrm{X} 1$ and Y. The level of significant is Sig $(0,000)<\alpha(0,01)$, consequently, $\mathrm{H} 0$ is rejected. It means that between students' learning motivation and writing achievement havehigh significant correlation of the eleventh graders of SMA ETHIKA Palembang. From this finding, it can be concluded that if students' learning motivation is high, so the students' writing achievement is good.

The second is the correlation between students' writing anxiety (X2) and writing achievement (Y) is Ryx2 $=-0.053$, consequently, there is correlation between X2 and Y. The level of significant is Sig $(0.067)>\alpha(0,05)$, consequently, HO is accepted. It means that between students' writing anxiety and writing achievement did not have significant correlation of the eleventh graders of SMA ETHIKA Palembang.

The third is the correlation between students' learning motivation (X1), writing anxiety (X2), and writing achievement (Y) is $\operatorname{Ryx} 1 \times 2=0.845$, consequently, there is correlation between $\mathrm{X} 1, \mathrm{X} 2$, and $\mathrm{Y}$. The significance level of $\mathrm{X} 1$ on $\mathrm{Y}$ is $\operatorname{Sig}(0,000)$ and $\mathrm{X} 2$ on $\mathrm{Y}$ is $\operatorname{Sig}(0,000)<\alpha(0,05)$,consequently, H0 is rejected. It means that between students' learning motivation, writing anxiety, and writing achievement have high significant correlation of the eleventh graders 
of SMA ETHIKA Palembang. From this finding, it can be concluded that if students' learning motivation is high, writing anxiety is low, so the students' writing achievement is good.

Based on the result of the study, it can be understood that motivation is the important thing that should be had by the students. By motivation students will curious to study. Motivation can build up students' mind to explore the world. To get all of them, students should be interested to study. Higher motivation will make students enjoy learning English, students get ideas, opinions, and experiences that can be drawn in written text. Besides that, writing anxiety is also important in teaching English. Teacher should teach writing skill well in the classroom. Writing skill should be taught integrated. Before teaching writing skill the teacher should encourage the students to interest in the class, teacher leads them to be interested in writing texts. And then teacher teaches writing integrated. Teacher asks the students to comprehend the text by giving some questions relate to the text itself. Students are asked to discuss what the text is about and leads them to understand the content of text. Beside understanding contents of the text, the students also have to know the organization and the functional of the text. After they have known the content of text, teacher asks them to write the text by using their own words in good organization and teacher should be closer to the students because it can make their writing anxiety lower.

\section{REFERENCES}

Arikunto, S. 2010. Prosedur Penelitian: Suatu Pendekatan Praktik. Jakarta: Rineka Cipta.

-----------.2006. Prosedur Penelitian: SuatuPendekatanPraktik. Jakarta:RinekaCipta.

Brown, H.D. -.2007. Principle of Language Learning and teaching.USA.Pearson Education.

Budiyani, S. 2013. Writing Tips. Yogyakarta. PT. Citra Aji Pratama.

Cheng, Y.S. 2004. A measure of second language writing anxiety: Scale development and preliminary validation. Journal of second language writing, 13(4), 313-335.

Creswell, J.W. 2011. Educational research: Planning, Conducting, and Evaluating Quantitative and Qualitative Research. New Jersey: Pearson education. 
Emzir. 2008. Metodologi Penelitian Pendidikan Kuantitatif dan Kualitatif. Jakarta: Rajawali Press.

Fraenkel, J., Norman E.W., Hellen H.H. 2011. How to Design and Evaluate Research in Education. United States: San Francisco State University.

Graham, S. 1997. Effective language learning. Clevedon, UK: Multilingual Matters, Ltd.

Hedge, T. 1992. Writing. Oxford: Oxford University Press.

Hesti, W.A. 2012. The differences among Writing Anxiety, Gender, and Writing Achievement of English Study Program Students of PGRI University Palembang. Palembang: Universitas Sriwijaya Palembang.

Lefrancois, G.R. 1997. Psychology for teaching. Belmont, CA: Wadsworth Publishing Company.

Narayan, R.A. 2008. Some Factors Affecting English Learning at Tertiary Level. Iranian Journal of Language Studies (IJLS), 2(4), 485-512. Retrieved from http://www.ijl.net/volemes/volume2issue4/narayan1.pdf

Rose, M. 1985. Complexity, rigor, evolving method, and the puzzle of writer's block: Thoughts on composing-process research. In M. Rose (Ed), when a writer can't wrire (pp.227-260). NY: Guilford Press.

Sedarwati, Th. M. 2007. Look Ahead 3: An English Course for Senior High School Students Year XII. Jakarta: PT Gelora Aksara Pratama.

Siahaan, S. 2008. Issues in Linguistics. Yogyakarta: Graham Ilmu.

Sugiono. 2012. Metode Penelitian Kuantitatif, Kualitatif dan R\&D. Bandung: Alfabeta, CV.

Tarigan, H. G. 2008. Berbicara sebagai Suatu Keterampilan Berbahasa. Bandung: Angkasa. 